\title{
IAMJ
}

INTERNATIONAL

AYURVEDIC

MEDICAL JOURNAL

[.] 1

\section{CRITICAL REVIEW ON GODUGDHA (COW MILK) HEALTH BENEFITS AND HAZARDS}

\author{
Manisha M. Thakare' ${ }^{1}$ Deepak K. Dobade ${ }^{2}$ \\ ${ }^{1}$ Assistant Professor, Swasthawritta Department, D. Y. Patil Ayurved College, Pimpri, Pune, Maharashtra, India \\ ${ }^{2}$ Assistant Professor, Rachana Sharir Department, Siddhakala Ayurved Mahavidyalaya, Sangamner, Maharashtra, \\ India
}

Corresponding Author: thakaremanisha365@gmail.com

https://doi.org/10.46607/iamj2508122020

(Published online: December 2020)

Open Access

(C) International Ayurvedic Medical Journal, India 2020

Article Received: 00/10/2020 - Peer Reviewed: 00/11/2020 - Accepted for Publication: 00/11/2020

\section{Check for updates}

\begin{abstract}
Milk is touted as complete food. Cow milk is said to be one of the most commonly consumed amongst the many kinds available. Human beings are the only species that drink the milk of another species, specially cow's milk. Besides humans no species drinks milk beyond their natural age of weaning or drinks the milk of another species. Some Constituents of Cow milk may be useful, and some may be harmful to human beings. Depending upon the variants of $\beta$-casein (30\% of cows' milk-proteins) found genetically, the Milk is divided into A1 and A2 type. Cow milk is deficient in essential fatty acids as compared to human milk. A1 and A2 milk variants differ by a single amino acid. A1 type of milk has serious health hazards on humans. In order to fulfill the increasing demand and make profitable business, today the farmers are excessively using the Chemical drugs, antibiotics, forced feeding plans, Hormones and specialized breeding plan to increase the milk production. All these additives are having serious health adverse effects on both animals and consumers of Godugdha (Cow milk). The present review article is compiled from many articles and research papers collected from different websites along with related materials from ancient Ayurvedic classics.
\end{abstract}

Keywords: Cow milk, Godugdha, Linoleic acid, Rasayan 


\section{INTRODUCTION}

Milk has been enjoyed throughout the world for thousands of years. Right from the birth, Milk plays a vital role in the life of all mammals. The Constituents of milk of each and every mammalian species is unique in its sense and it is used to meet the requirements of that particular mammalian species. The milk of one species may not be suitable to the requirements of another species and may leads to harmful effect on them. Cow's milk is a daily staple in many countries and has been for epochs. While it's still a popular food, recent studies suggest milk may have harmful effects on the body. Other research, however, points out the health benefits of dairy. In Ayurvedic literature Milk is considered as wholesome to the body and should be consumed regularly. Cow's milk composed of about $87 \%$ water, $3 \%$ $4 \%$ fat, $3.5 \%$ protein, about $5 \%$ lactose, and $1.2 \%$ minerals, with few variations depending on the breed considered $^{1}$. Depending upon the variants of $\beta$-casein $(30 \%$ of cows' milk-proteins) found genetically, the Milk is divided into A1 and A2 type. Among the genetic variants of $\beta$-casein, the problematic type of $\beta$-casein protein found in milk is the A1 $\beta$-casein, devil in the milk (By Keith Woodford). A1 protein variant is commonly found in milk from crossbreed and European breeds of cattle. A2 milk is found basically in indigenous (Desi) cows and buffaloes. A1 and A2 milk variants differ by a single amino acid, resulting in differential secondary structure and enzymatic hydrolysis, i.e. A1 $\beta$-casein liberates the $\beta$-casomorphin-7 (BCM7). BCM7 leads to type-1 diabetes, digestive, immune and brain development changes, thus A1 type of milk has serious health hazards on humans ${ }^{2-3}$.

Materials and Methods: The materials and Methodology for this critical review study have been collected from various Scientific Sources like ancient Scientific literatures, International Publications, Magazines etc.

\section{Godugdha (Cow Milk) Ayurvedic View}

According Charak Acharya Godugdha is Madhura (Sweet) in taste, Sheeta Virya (Cold) in potency, Mrudu (Softening the Cells/tissues), Snigdha (Demulcent), Bahala (Thick), Shlakshna (Smooth), Picchila (Sticky in nature), Guru (Heavy), Manda (Dull), Prasanna
(Causes enthusiasm). Acts as Rasayana (Vitalizer), Oja Vruddhi (Increases essence of all the seven Dhatus; Rasa-Rakta-Mamsa-Meda-Asthi-Majja-Shukra). It is best among the Jivaniya Padarthas (Life enhancing/promoting Substance) $)^{4}$. According to Sushrut Acharya Cow milk is Alpa Abhishyandikaraka (Not much causes the blockage of the channels), Snigdha (Demulcent), Guru (Heavy), Rasayana (Tissue vitalize), Rakta-Pitthara, Sheeta (Cold) in potency, Madhura (Sweet) in taste, Madhura Vipaka (Sweet) at the end of the digestion), Jeevaniya (Sustains life), Vata-Pitta Nashaka (Subsides Vata and Pitta Doshas) ${ }^{5}$.

\section{Godugdha (Cow milk) Gun Karma}

Ras- Madhur, Gun-Guru, Snigdha, Virya- Sheet, Vipak-Madhur

According to Vagbhat Acharya Godugdha is Jivaniya (Life promoting), Rasayana (Vitality enhancer), Kshataksheena Hita (Useful in injury and emaciation), Medhya (Brain tonic), Balya (As a Tonic), Stanyakara (Induces breast milk), Sara (Laxative), Cures Shrama (Lethargy and exhaustion), Bhrama (Confusion), Mada (Intoxication, Shwasa (Dyspnoea), Kasa (Cough), Atitrishna (Excess thirst), Kshudha (Excess appetite), Jeerna Jwara (Chronic fever), Mutrakrichra (Dysuria), Raktapitta (Haemorrhage) ${ }^{6}$. According to Raj Nighantu Godugdha is Pathya (Can be taken in all diseases), Ruchikaraka (Taste promoter), Swadista (Tasty), Snigdha (Demulcent), Pitta and Vata Vikara Nashaka (Subsides Vata and Pittaja diseases), Kantiprada (Improves complexion), Prajna (Improves knowledge), Buddhi (Improves memory), Medha (Helps to sustain memories), Angapusthiprada (Gives strength to the body ), Virya Vriddhikara(Increases semen) ${ }^{7}$.

\section{Colour of Cow with Therapeutic Properties}

The Milk of black cow is more potent and subsides Vata Dosha, the yellow cow milk pacifies Pitta, and Vata Doshas, and the white cow milk is Guru (Heavy), and the red colour cow's milk pacifies Vata Dosha. The cow milk from Jangala Pradesha (Jungle region) is Guru (Heavy), Sneha (Fatty) ${ }^{8}$.

\section{Modern View}

Proteins in Milk 
Godugdha (Cow's milk) naturally contains the abundant amount of protein needed for her calf. That amount of protein is not only unnecessary but unhealthy for human beings. Excess amount of protein in our diets causes calcium to leach out of our bones. This can be a cause of osteoporosis. Research Studies have also shown that there are certain proteins in cow's milk which acts as allergen particularly to breast fed infants. The Most common problems in children are Gastrointestinal disorders, acute gastrointestinal blood loss, milk borne infections, lack of minerals, abdominal Colic pain, bedwetting, asthma, intestinal bleeding and diabetes ${ }^{9}$. Adults could be affected with coronary deaths, hardened and narrowed arteries, kidney disorders, arthritis and the more serious diseases like leukemia, lymphoma and cancer of different organs particularly genital organs. Some specific proteins in the milk may be responsible for insulin-dependent diabetes (Type1) which usually begins in childhood ${ }^{10}$.

\section{Sugar and Fat in Milk}

Lactose (Milk Sugar) is not easily digestible by humans and can cause GIT disorders like Gas, Bloating and dysentery. If digested the end products of lactose are simple sugars like glucose and galactose. Galactose is a disaccharide which needs to be broken down into monosaccharides, glucose. Galactose as such has been implicated in genital cancers ${ }^{11}$.

\section{Cow Milk Rich Source of Calcium and Vitamin D}

Cow's milk is a rich source of calcium. Researchers from the Harvard School of Public Health revealed that more consumption of milk and other calcium-rich foods appears to be a myth to prevent the chances of osteoporosis and easy bone fractures in adult humans. Cow Milk consumption causes more health risks to young ones, to whom whole cow's milk can contribute to deficiencies in several nutrients, including iron, essential fatty acids and vitamin E. But Cow milk is very high in vitamin D and may result in hypervitaminosis ${ }^{12}$.

\section{DISCUSSION}

Cow milk is a trusted form of health drink and known as a wholesome beverage for the holistic development of the body. Scientist Dr Corran McLachlan has studied the A2 protein and identified that the health of consumers of A2 variety of cow milk is intact. In India, the Karnal-based National Bureau of Animal Genetic Resources (NBAGR) conducted research on 5 main species of the Indigenous cows viz, Sahiwal, Red Sindhi, Tharparkar, Gir and Rathi. Milk of these species were seen to contain A2 casa-beta proteins of $100 \%$ while the exotic Jerseys and the Holstein Friesian showed only $60 \%$ content of the A2 casa-beta proteins. Research studies have proved that consumption of the A1 beta-casein milk leads to milk intolerance as well as range of auto-immune diseases. A1 milk is called as 'the devil in the milk'. Keith Woodford in his book titled "Devil in the Milk: Illness, Health, and the Politics of A1 and A2 Milk", has explained the jeopardies involved in drinking the A1 milk of the Exotic Cow species. Many research studies conducted across the world stated a direct association between a population's exposure to A1 cow's milk and the incidence of autoimmune disease, heart disease, type 1 diabetes, autism, and schizophrenia. The native Indian cow milk or A2 milk has coolant effect on the body as well as mind and the milk is sweet in taste as well as it improves Ojas which is the element responsible for immunity. A2 milk rejuvenates and nourishes the body tissues while acting as a natural aphrodisiac as well as enhances life expectancy. Cow milk and its derivatives contribute essential micro and macro nutrients to the diet, especially in infancy and childhood where bone mass growth is in a critical phase.

\section{CONCLUSION}

Godugddha (Cow's milk), due to its composition, can facilitate the appropriate intake of some important macro- and micronutrients throughout life. Many available research evidences from the scientific literature suggests that the associations between milk consumption and health are favorable. Almost all the classical texts have revealed that the Cow milk have tremendous therapeutic action and is mostly sweet in taste, Snigdha, sweet at the post digestive effect, cold in potency. It is Vata-Pitta Shamaka (Subsides Vata and Pitta Doshas), Stanya Janana (Galactogogue), Jivaniya (Life promoting), Vrishya (Aphrodisiac) and Rasayana (Vitalizer). The A2 milk (Desi cow's milk) should only be 
endorsed as it prevents milk related health complications, which are due to A1 milk (Exotic cattle's milk).

Thus, Cow Milk, if consumed according to Classical guidelines and in moderate quantity, can continue to be part of human diet.

\section{REFERENCES}

1. Muehlhoff E, Bennett A, McMahon D; Food and Agriculture Organisation of the United Nations (FAO). Milk and Dairy Products in Human Nutrition. Rome (Italy): Food and Agriculture Organisation of the United Nations; 2013. doi:10.1186/1471-2458-11-95.

2. Barnett MPG, McNabb WC, Roy NC, Woodford KB, Clarke AJ, et al. (2014) Dietary A1 beta-casein affects gastrointestinal transit time, Dipeptidyl peptidase-4 activity, and inflammatory status relative to $\mathrm{A} 2 \mathrm{~b}$-casein in Wistar rats. Int J Food Sci Nutr 65, Page no.720-727.

3. Cavallo MG, Fava D, Monetini L, Barone F, Pozzilli P (1996) Cell-mediated immune response to beta casein in recent-onset insulin-dependent diabetes: implications for disease pathogenesis. Lancet 348 (9032) Page no. 926-928

4. Acharya Charaka, Charaka Samhita, Sutrasthana 27th Chapter, Shloka No-217-218, Charaka Chandrika Hindi commentary of Agnivesha, edited by Dr. Bramhananda Tripathi, Chaukhamha Surabharati Prakashana, Varanasi, Reprint, 2002; Page No-526.

5. Acahrya Sushruta, Sushruta Samhita, Purvardha, Sutrasthana 45th Chapter, Shloka No-50, Ayurveda Tatva Sandipika, Hindi commentary, edited by Kaviraja Dr. Ambikadatta Shastry, Chaukhamba Sanskrit Samsthan, Varanasi, Reprint, Page No-223

6. Srimad Vriddha Vagbhata, Asthanga Sangraha, Sutrastana 5th Chapter, Shloka No- 21-22, Saroj Hindi Commentary by Dr. Ravi Datta Tripathi, Delhi, Chaukhambha Sanskrit Pratisthan, Reprint 2003, Page No-69.

7. Pandit Narahari, Raj Nighantu, Ksheeradi Varga, Shloka No- 10, redacted by Indradeva Tripathi, Varanasi, Chaukhamba Krishnadas Academy, 2003, Page no-506

8. Acharya Bhavamishra of Bhavaprakasha Nighantu, 6th Chapter, Dugdha Varga, Shloka No-7-13, by Dr. Bulusu Sitaram, Volume 1, Chaukhambha Orientalia, Varanasi, First edition 2006, Page No- 525

9. Ziegler EE, Fomon SJ, Nelson SE, et al. Cow Milk Feeding in Infancy: Further Observations on Blood Loss from the Gastrointestinal Tract. J. Pediatr. 1990; 116: Page No.8-11.
10. Scott FW. Cow Milk and Insulin-Dependent Diabetes Mellitus: is There a Relationship? $A m$ J CL in Nutr.,1990; 51:Page no. 489-91.

11. Cramer DW, Willett WC, Bell DA, et al. Galactose Consumption and Metabolism in Relation to the Risk of Ovarian Cancer. Lancet. (1989); 2: Page no.66-71.

12. Jacobus $\mathrm{CH}$, Holick MF, Shao Q, et al. Hypervitaminosis D Associated with Drinking Milk. New Engl J Med. 1992; 326: Page no.1173-7.

\section{Source of Support: Nil Conflict of Interest: None Declared}

How to cite this URL: Manisha M. Thakare \& Deepak K. Dobade: Critical Review On Godugdha (Cow Milk) Health Benefits And Hazards. International Ayurvedic Medical Journal \{online\} 2020 \{cited December, 2020\} Available from: http://www.iamj.in/posts/images/upload/4_4.pdf 